\title{
Input Trade Liberalization and Export Product Scope: Evidence from China
}

\author{
Chunming Zhao \\ Business School, Beijing Normal University, Beijing 100875, China \\ Email: cmzhao@bnu.edu.cn \\ Qun Zhang (Corresponding author) \\ Business School, Beijing Normal University \\ 19 Xinjiekouwai, Haidian District, Beijing 100875, China \\ Tel: 0086-188-1314-9267Ｅ-mail: zhangqun_jane@163.com
}

Received: May 30, 2016 Accepted: June 16, 2016

doi:10.5296/ber.v6i2.9530 URL: http://dx.doi.org/10.5296/ber.v6i2.9530

\begin{abstract}
This paper explores the impact of input trade liberalization on export product scope of firms in industries with different scope for product differentiation. Firm- and industry-specific tariffs are measured to reflect cost effect (intensive margin) and new input effect (extensive margin) of input tariff reductions. Using tariff data and product-level trade data for 2002-2006, we find that while firms in differentiated product scope expand export product lines greatly, firms in non-differentiated product sector do not expand export product scope significantly, which is robust to different definitions of varieties.
\end{abstract}

Keywords: Input trade liberalization, Product scope, Scope for product differentiation

\section{Introduction}

Multi-product firms (MPFs) contribute a large percent to international trade. In China, they account for $80 \%-81 \%$ of the total number of all exporting firms and the value (93\%-96\%) of the total following China's acceding to World Trade Organization (Peng and Xia, 2013). Since the success of multi-product exporters in the global marketplace means a lot to sustaining China's exporting growth, what makes a successful multi-product exporter?

Recent literature on multi-product firms shows that product scope is one of the most 
important sources of exporters' success in international trade ${ }^{1}$ (see, Eckel and Neary, 2010; Goldberg et al., 2010; Dhingra, 2013; Nocke and Yeaple 2014; Arkolakis et al 2015; Flach and Irlacher, 2015; Hottman et al., 2015). Introducing a new product or a new variety of existing products and thus expanding the product lines increase exporters' revenues in the global marketplace. However, it would prove difficult if accessing varieties of key inputs is too costly.

Input trade liberalization provides domestic firms great opportunities to access to cheaper and previously unavailable inputs (Goldberg et al., 2010). For one thing, reductions in the import prices of existing inputs raise the likelihood that a firm can manufacture/export previously unprofitable products ("intensive margin"). For another, if an input is an essential element of a product, input tariff reductions relax technological constraints facing such producers via access to new imported input varieties that were unavailable prior to the liberalization (“extensive margin”).

Recent theoretical and empirical literatures on multi-product firms show that multi-product firms are large relative to the markets in which they operate (e.g., Eckel and Neary, 2010; Dhingra, 2013; Eckel et al., 2015; Hottman et al., 2015). As a result, reductions on inputs would not lead all these "granular" firms to expand their product lines since introducing a new variety will, to some extent, reduce the sales of their existing varieties ("cannibalization effect").

Though cannibalization effects exist in the "granular" firms, the extent to which a new variety cannibalizes a firm's existing varieties hinges on the substitutability across varieties within a firm. Specifically, if a firm's varieties are differentiated and less substitutable with each other, then most sales of a new variety will come from other firms' varieties, which imply a low cannibalization rate. In contrast, if a firm's varieties are homogeneous and more substitutable with each other, then a large percent of a new variety's sales will come at the expense of the sales of the firm's existing varieties, which implies a high cannibalization rate. Since the goal of all firms is to realize profit or revenue maximization, in the former case, firms have great incentives to introduce new varieties and thus expand their product lines. However, in the latter case, considering that manufacturing a new variety will lead to sales reductions of all existing varieties and hence may reduce the total revenue, firms may not introduce a new variety or only introduce a small number of new varieties.

Relying on tariff data, product-level trade data, we construct firm-and industry-specific tariff index, respectively, to reflect the intensive and extensive margin of input trade liberalization using time-invariant input share as weight to avoid the endogenous relationship between tariffs and imports. In addition, since the main interest of our paper is firms' export scope, we make three definitions of firms' export varieties to show that the results are not sensitive to our definition of varieties. In order to investigate heterogeneous impacts of input trade

\footnotetext{
${ }^{1}$ In addition to product scope, sources of firms' success can also be attributed to costs (e.g., Melitz, 2003; Chaney, 2008; Melitz and Ottaviano, 2008; Mayer et al., 2014), product appeal (see, Baldwin and Harrigan, 2011; Amiti and Khandelwal 2013; Hallak and Sivadasan, 2013; Antoniadess, 2015 among others) and markups (See, e.g., De Loecker and Warzynski, 2012; De Loecker et al., 2015).
} 
liberalization on firms' export product scope in industries with different scope of product difference, we also classify export products into differentiated and homogeneous goods using Rauch (1999) classification.

As we show, the Chinese data provide robust confirmation of the prediction: comparing changes of export product scope of firms in industries with different scope of product differentiation, we find that while firms in differentiated product scope expand export product scope greatly, firms in non-differentiated product sector do not expand export product scope significantly. Moreover, it shows that our results are robust to different definitions of varieties. One of the challenges in studying the impacts of input trade liberalization is the potential endogenous problem because firms in low-productivity sectors would lobby the government for protection to maintain import tariff at a relatively high level (Goldberg et al., 2010; Yu, 2014; Fan et al., 2015; Bas and Kahn, 2015). I control for such reverse causality by using an IV approach.

Our paper builds on and extends the existing literature on product scope of multiproduct firms (Goldberg et al., 2010; Qiu and Yu, 2014). While these papers emphasize the role of market expansion effects, competition effects and input effects, we take a step further towards investigating heterogeneous impacts of input trade liberalization on firms' export product scope in industries with different scope of product difference. Our paper is also closely related to the recent literature on heterogeneous responses of firms in industries with different scope of product difference to trade liberalization (Dhingra, 2013; Flach and Irlacher, 2015). They find that firms in highly differentiated industries will invest more in product innovation and that market expansion benefits domestic firms for increasing access to foreign markets and exploiting economies of scale in innovation. Differing from these papers, the focus of our study is not on different strategies of investment, but on export product scope.

The remainder of the paper is structured as follows. In Section 2, we describe the data we use in our analysis. In section 3, we provide underlying mechanisms and empirical equations. In section 4, we estimate the impacts of input trade liberalization on firms' export product scope. Section 5 concludes.

\section{Data}

The period under study is from 2002 to 2006. To investigate the impacts of input trade liberalization on Chinese firms' export product scope, we rely on two disaggregated data: tariff data and product-level trade data.

\subsection{Tariff Data}

China's tariffs at HS6-digit are available at WTO website, which provides two groups of tariffs: MFN applied tariff and bound tariff, each including number of AV duties, average of AV duties, minimum AV duty and maximum AV duty, for the purpose of our study, we rely on the information of number of AV duties and average of AV duties under MFN applied tariff to measure firm-specific and industry-specific tariffs. 


\subsection{Product-Level Trade Data}

Product-level trade data (including export and import) are accessed from China's General Administration of Custom. This database includes monthly firm level imports and exports at the 8-digit HS product-level. Trade data are reported free on board (f.o.b.) in U.S. dollars. Specifically, the information includes name, ownership and address of each trading firm, the country of origin of imports and country of destination of exports, value, quantity, measurements of unit of each HS8-digit product, and 18 different custom regimes ${ }^{2}$.

Since the aim of this paper is to examine the impact of input trade liberalization on export product scope of manufacturing firms, we take the following procedure:

(1) We only keep firms that both export and import under ordinary trade regimes;

(2) We restrict our sample to firms that importing intermediate inputs only through ordinary trade regime. Therefore, we exclude firms that trade also under other regimes and that switch from ordinary to other regimes.

(3) Following Ahn et al. (2011) and Tang and Zhang (2012),we delete intermediary firms whose Chinese names includes "trading", "exporting", and "importing";

(4) We use the conversion table from the UN Comtrade to merge HS6-digit products with SITC (Rev.2) 4-digit level and keep firms that produce products between 5000 and 8000;

(5) In order to calculate firm- and industry- specific input tariffs, we need to distinguish imports of intermediate inputs from imports of final goods. To identify intermediate inputs, we use the Broad Economic Categories (BEC) classification from the United Nations that organizes HS6 products into intermediate and capital and final goods ${ }^{3}$;

\section{Measurement}

\subsection{The Measurement of Tariffs}

As mentioned above, input trade liberalization impacts domestic exporters' product scope through both intensive margin and extensive margin. Accordingly, it is important to construct proper tariff measures which reflect the intensive margin and extensive margin of input trade liberalization.

In doing so, first, we construct a firm-specific tariff index to reflect the intensive margin of input tariff reductions, which is computed as a weighted average of tariffs on the inputs imported by the firm:

\footnotetext{
2 Since our aim is to explore the tariff reductions on firms' export product scope, we only rely on ordinary regime. Specifically, we restrict our sample to firms that importing intermediate inputs only through ordinary trade regime. Therefore, we exclude firms that trade also under other regimes and that switch from ordinary to other regimes.

${ }^{3}$ Following Goldberg et al. (2010), we group intermediate and capital into inputs.
} 


$$
F I T_{f t}=\sum_{k} \frac{i m p_{f, \text { initial_year }}^{k}}{\sum_{k} i m p_{f, \text { initial_year }}^{k}} \tau_{k t}
$$

Where $\tau_{k t}$ is the tariff of input $k$ in $t ; \frac{i m p_{f, \text { initial_year }}^{k}}{\sum_{k} i m p_{f, \text { initial } \_ \text {year }}^{k}}$ is firm $f$ 's import share of input $k$ in the total import value in the first year the firm appears in the sample, which measures the tariff reductions on firm's available imported inputs ${ }^{4}$. According to $\mathrm{Yu}$ (2014) and Bas and Kahn (2015), using constant (time-invariant) weights to calculate firm-specific tariffs also avoid the well-known endogeneity between tariff and a firm's imports. Since tariff is negatively correlated with import, we would calculate a downward biased firm-specific tariff if we use current import share of inputs as weights.

In addition, input tariff reductions also benefit domestic firms by providing access to previously unavailable new products or new varieties of existing products, enabling them to introduce new varieties and expand the product lines. Therefore, similar to $\mathrm{Yu}(2014)^{5}$, we construct an industry-specific input tariff index to reflect this extensive margin of input tariff reductions. In particular, the measurement of industry-specific input tariff index proceeds in three steps. The first step is to calculate the average output tariff level of each CIC4-digit industry ${ }^{6}$. Utilizing the conversion table between HS8-digit products and GB/T codes (CIC4-digit) provided by Upward et al. (2013), we first match HS8-digits with CIC4-digits, then we match HS6-digits to tariff table provided by WTO and measure the average output tariff level of each CIC4-digit industry according to the following formula:

$$
\operatorname{COT}_{i t}=\frac{\sum_{k} \tau_{k t} \cdot \text { num }_{k t}}{\sum_{k} \text { num }_{k t}}
$$

Where $\tau_{k t}$ is the average tariff of HS6-digit product $k$ in $t$; num $m_{k t}$ is the number of duties. As showed in the formula, the average output tariff level of each CIC4-digit industry is obtained by taking a simple average of all HS6-digit products within the industry.

The second step matches IO sectors ${ }^{7}$ with CIC4-digits, and then calculates the average output tariff of each IO sector which is also obtained by taking an average of all CIC4-digits

\footnotetext{
${ }^{4}$ We classify all the hs6 products imported by the firm into three categories: intermediate input, capital and final goods according to BEC classification, and following Nouroz (2001) and Goldberg et al. (2011), we assign the first two as inputs.

${ }^{5}$ While $\mathrm{Yu}$ (2014) calculated the sector output tariffs at the two-digit Chinese industry classification (CIC), the sector output tariffs in this paper is calculated at the four-digit CIC level which is reported by the firm-production data.

${ }^{6}$ Note that since CIC codes are adjusted in 2003, as in Yu (2014), we make the adjustment in our sample.

${ }^{7}$ We adopt the input-output table from 2002 since our data sample is between 2002 and 2006.
} 
within each IO sector.

The third step is to measure the average input tariff of each CIC4-digit. The CIC4-digit industry-specific tariff index is measured by

$$
\operatorname{CIT}_{i t}=\left(\frac{i n p u t_{n i}^{2002}}{\sum_{n} i n p u t_{n i}^{2002}}\right) \tau_{n t}
$$

Where $C I T_{i t}$ denotes the CIC4-digit industry-level input tariffs facing firms in industry $i$

in year $t ; \tau_{n t}$ is the import tariff of input $n$ in year $t ; \frac{i n p u t_{n i}^{2002}}{\sum_{n} i n p u t_{n i}^{2002}}$ is the input share of input $n$. Likewise, Use constant input shares to measure the industry-level input tariff, enabling us to avoid the endogeneity between tariff and inputs.

\subsection{Degree of Product Differentiation}

As the goal of this paper is to explore the effect of input trade liberalization on export product scope of multi-product firms in industries with different scope for product differentiation, we match hs6-digits with Rauch (1999) classification of goods ${ }^{8}$. Rauch (1999) classifies all 4-digit SITC trade products into homogeneous goods and differentiated goods. Based on this classification, we use two approaches to classify exporters that export both differentiated and homogeneous goods into firms exporting differentiated products/varieties and firms exporting homogeneous products. The first approach is based on the number of 4-digit SITC products. specifically, we calculate and compare the number of differentiated and homogeneous 4-digit SITC products, respectively, each firm exports, if the former is larger (smaller) than the latter, we take this firm as the one that export differentiated (homogeneous) products or varieties; the second method relies on the export values of 4-digit SITC products. i.e., we calculate and compare the total export values of differentiated and homogeneous 4-digit SITC products, respectively, each firm exports. If firms' most export values come from differentiated 4-digit SITC products, we take this firm as the ones that export differentiated products.

\section{Specifications and Empirical Results}

\subsection{Specifications}

Input tariff reductions impacts firms' export product scope through offering domestic firms increasing access to cheaper and previously unavailable inputs. The former lowers the firms' production cost for existing imported products or varieties, enabling firms to produce and export new products of higher production cost; the latter relaxes the technological constraint facing domestic firms since lower input tariffs increase firms' access to previously

\footnotetext{
${ }^{8}$ I proceed with the following two steps to match hs6-digits with Rauch (1999) classification of goods: the first step is to match HS6-digits with Standard International Trade Classification (SITC, Rev.2) using conversion table available at: http://unstats.un.org/unsd/cr/registry/regdnld.asp? Lg=1; the second step matches the SITC (Rev.2) with Rauch (1999) classification.
} 
unavailable inputs.

Though reductions on inputs provide domestic firms great opportunities to expand their product lines, the responses are different across firms in industries with different scope of product. Specifically, the number of products supplied by each firms is determined by whether the increase in profits from introducing an additional minus the reduction in profits from reduced sales of existing is greater than the fixed cost of introducing the new (Hottman et al., 2015). Since the cannibalization effect decreases with the scope of product differentiation, net profit brought by new varieties is greater in highly differentiated industries. As a result, firms in highly differentiated industries are more likely to expand their product varieties, whereas firms in non-differentiated industries may not. Therefore, we consider the following two equations to explore the impacts of input trade liberalization on firms' export product scope:

$$
\begin{aligned}
& \ln \left(n_{i t}\right)=\gamma_{i}+\gamma_{t}+\beta C I T_{q t}+\beta C I T_{q t} \cdot \operatorname{dif}_{i}+\varepsilon_{i t} \\
& \ln \left(n_{i t}\right)=\gamma_{i}+\gamma_{t}+\beta F I T_{i t}+\beta F I T_{i t} \cdot \operatorname{dif}_{i}+\varepsilon_{i t}
\end{aligned}
$$

Where $n_{i t}$ is the number of products or varieties exported by firm $i$ at time $t ; C I T_{i t}$ and $F I T_{i t}$ are industry $(q)$-specific and firm-specific input tariff faced by firm. $d i f_{i}$ denotes whether the products or varieties a firm exports are differentiated ( $\operatorname{dif}_{i}=1$ )or homogeneous goods $\left(\right.$ dif $\left._{i}=0\right) ; \gamma_{i}$ is firm-level fixed effect and $\gamma_{t}$ is year fixed effect.

Based on the classification of firms into exporting differentiated products and homogeneous products as well as the measurement of firm-specific and industry-specific tariffs in the previous section, in this section, we turn to estimate the impacts of input trade liberalization on the export product scope of firms in industries with different scope for product differentiation using the firm-specific and industry-specific tariff measures. Since we seek to explore the impacts of tariff reductions on firms, our remaining dependent variables are firm-specific.

Additionally, as our main interest is to investigate the input tariff cuts on export product scope, we calculate the number of products/varieties that a firm exports. Specifically, following Goldberg et al., (2010), we define HS6 product-country as varieties and calculate the number of HS6 product-country varieties 9 . To show that the empirical results are not sensitive to our definition of varieties, we make another two definitions of firms' export varieties, i.e., HS8 codes and HS8 product-country and report the results in the section of

\footnotetext{
${ }^{9}$ In general, HS8 codes are taken as varieties, however, HS8 codes are not consistent overtime as mentioned in the previous section. With that, we take a HS6 product-country as a variety in our baseline results and report the HS8 codes in our robustness.
} 
robustness.

\subsection{Baseline Results}

We regress our first measure of product scope on firm-specific and industry-specific tariffs, respectively. The coefficients, report in columns 1 and 3 of Table 1, show a significant impact of input tariff reductions firm and industry level on firms' export product scope. The coefficients in these two columns imply that the impacts of input trade liberalization on product scope are mainly through the extensive margin. However, this initial specification does consider the role of product differentiation in the effects of input tariff reductions on firms' product scope. This makes it difficult to investigate the heterogeneous responses of firms in industries with differentiated scope of product differentiation. Therefore, in column 2 and 4 of Table 1, we introduce measures of product differentiation to examine the heterogeneous effects of tariff cuts across industries. it shows that input trade liberalization may lead domestic firms in homogeneous industries to reduce the export product lines though the coefficients are not significant. However, the negative and significant coefficient for cross term indicates that input trade liberalization do promote firms to introduce new products or new varieties of existing products and hence expand their export scope.

Table 1. Input Trade Reductions on The Number of (log) HS6-Country Varieties

\begin{tabular}{|l|l|l|l|l|}
\hline & $(1)$ & $(2)$ & $(3)$ & $(4)$ \\
\hline FIT & $-0.043^{* *}$ & -0.038 & & \\
& 0.016 & 0.033 & & \\
& & & $-0.035^{* * *}$ & $-0.042^{*}$ \\
& & & 0.005 & 0.027 \\
\hline 2.year & $0.205^{* * *}$ & $0.206^{* * *}$ & $0.167 * *$ & $0.165^{* *}$ \\
& 0.065 & 0.065 & 0.074 & 0.074 \\
3.year & $0.349^{* * *}$ & $0.347^{* * *}$ & $0.290^{* * *}$ & $0.286^{* * *}$ \\
& 0.07 & 0.07 & 0.088 & 0.088 \\
4.year & $0.514^{* * *}$ & $0.514^{* * *}$ & $0.445^{* * *}$ & $0.443^{* * *}$ \\
& 0.072 & 0.072 & 0.095 & 0.095 \\
5.year & $0.727^{* * *}$ & $0.726^{* * *}$ & $0.656^{* * *}$ & $0.653^{* * *}$ \\
& 0.074 & 0.074 & 0.097 & 0.097 \\
\hline FIT $\cdot$ dif & & $-0.01 * * *$ & & \\
& & 0.002 & & \\
CIT $\cdot$ dif & & & & $-0.09 * * *$ \\
& & & & 0.015 \\
\hline r2 & 0.863 & 0.934 & 0.887 & 0.964 \\
$\mathrm{~N}$ & 5425 & 5425 & 5425 & 5425 \\
\hline
\end{tabular}

Note: Table 1 regresses the (log) number of HS6-country variety on firm- and industry-specific tariffs and cross term with the scope of product differentiation. Regressions include firm fixed effects and year fixed effects. Robust standard errors are clustered by exporter year. Significance levels: ***0.01;**0.05;*0.10. 


\section{Macrothink}

\subsection{Robustness}

\subsubsection{Other Definitions of Varieties}

To certify our empirical results are not sensitive to the definition of a variety, we choose the number of HS8-country (Table2) and number of HS8 codes (Table3) as dependent variables, respectively and rerun the estimation equation. As shown in the table, our results are robust to alternative definitions of a variety. Specifically, consistent with the evidence in Table 1, the relationship between input tariff cuts and export product scope is particular pronounced for highly differentiated industries. Besides, the coefficients for industry-specific tariffs are still larger than that for firm-specific tariffs, which confirms the importance of the new variety margin.

Table 2. Input Trade Reductions on The Number of (log) HS8-Country Varieties

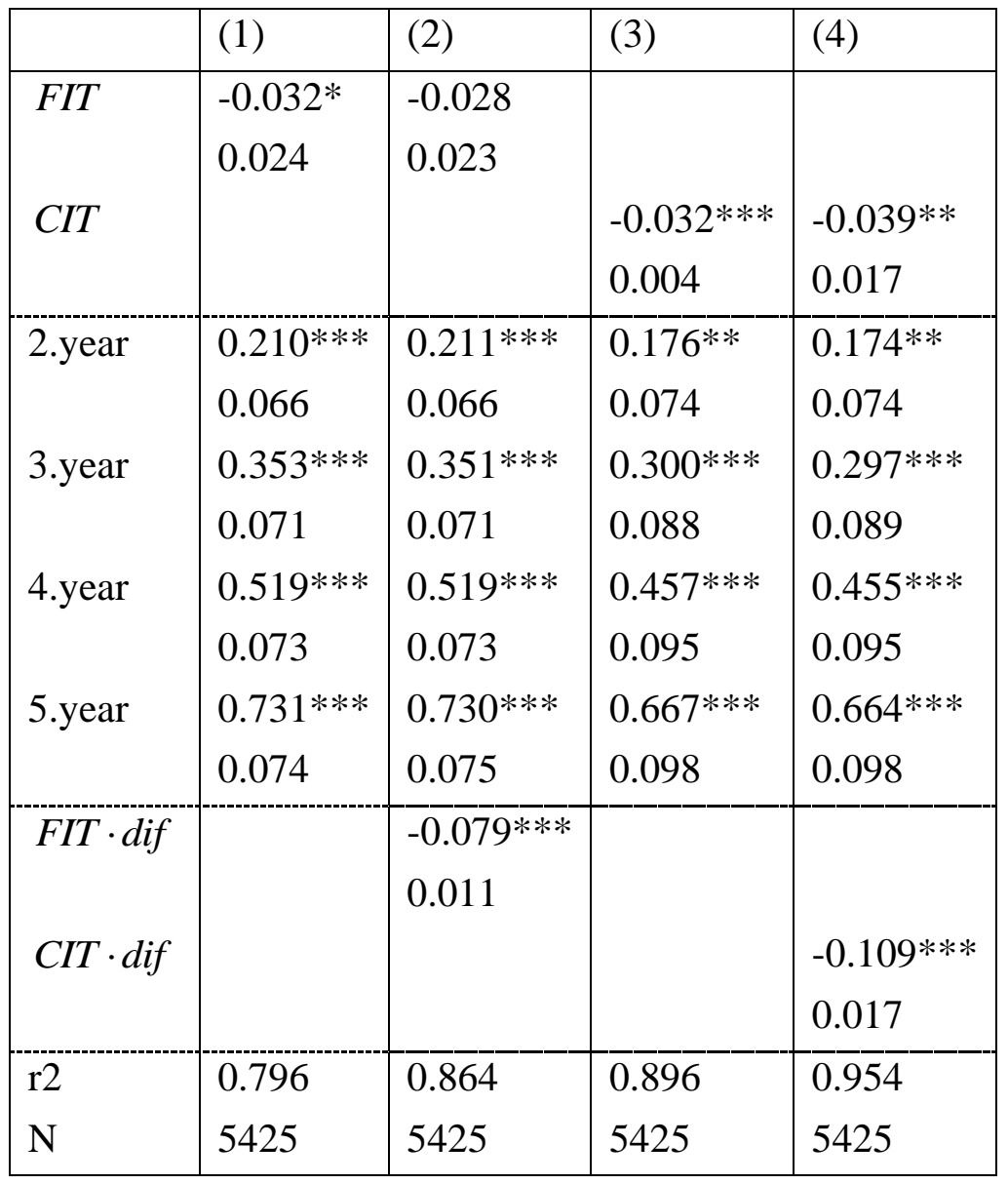

Note: Table 2 regresses the (log) number of HS8-country variety on firm- and industry-specific tariffs and cross term with the scope of product differentiation. Regressions include firm fixed effects and year fixed effects. Robust standard errors are clustered by exporter year. Significance levels: ***0.01; **0.05; *0.10.

Table 3. Input Trade Reductions on The Number of (log) HS8 Varieties

\begin{tabular}{|l|l|l|l|l|}
\hline & $(1)$ & $(2)$ & $(3)$ & (4) \\
\hline FIT & $-0.041^{*}$ & -0.021 & & \\
\hline
\end{tabular}




\begin{tabular}{|l|l|l|l|l|}
\hline & 0.026 & 0.023 & & \\
\hline CIT & & & $-0.046^{* *}$ & $-0.045^{*}$ \\
\hline & & & 0.026 & 0.025 \\
\hline 2.year & $0.110^{* * *}$ & $0.546^{* * *}$ & $0.455^{* *}$ & $0.453^{* *}$ \\
\hline & 0.057 & 0.054 & 0.045 & 0.055 \\
\hline 3.year & $0.347^{* * *}$ & $0.457 * * *$ & $0.300^{* * *}$ & $0.457 * * *$ \\
\hline & 0.045 & 0.054 & 0.088 & 0.089 \\
\hline 4.year & $0.564 * * *$ & $0.754 * * *$ & $0.234 * * *$ & $0.448^{* * *}$ \\
\hline & 0.037 & 0.045 & 0.034 & 0.045 \\
\hline 5.year & $0.467 * * *$ & $0.785 * * *$ & $0.345^{* * *}$ & $0.565 * * *$ \\
\hline & 0.057 & 0.076 & 0.045 & 0.086 \\
\hline FIT $\cdot$ dif & & $-0.076^{* * *}$ & & \\
\hline & & 0.009 & & \\
\hline CIT dif & & & & $0.093 * * *$ \\
\hline & & & & 0.014 \\
\hline $\mathrm{r} 2$ & 0.792 & 0.879 & 0.859 & 0.953 \\
\hline $\mathrm{N}$ & 5425 & 5425 & 5425 & 5425 \\
\hline
\end{tabular}

Note: Table 3 regresses the (log) number of HS8 variety on firm- and industry-specific tariffs and cross term with the scope of product differentiation. Regressions include firm fixed effects and year fixed effects. Robust standard errors are clustered by exporter year. Significance levels: $* * * 0.01 ; * * 0.05 ; * 0.10$.

Our empirical results are consistent with the evidence in Flach and Irlacher (2015), who find that firms in highly differentiated industries will invest more in product innovation and that exchange rate devaluation in Brazil benefits domestic firms for increasing access to foreign markets and exploiting economies of scale in innovation. However, they confirm the theoretical predictions proposed by Dhingra(2013) that the type of innovation depends on the industry-specific scope for differentiation. Compared with Flach and Irlacher (2015), our paper empirically confirm the theoretical prediction proposed by Nocke and Yeaple (2014) who predicts that trade liberalization expands the product scope of firms in industries with highly-differentiated industries.

\subsubsection{Endogeneity Issues}

There is a potential reverse causality problem in our estimation. Although China's tariff reductions are regulated by the WTO agreement, tariff reductions and product scope, to some extent, is endogenous. For example, firms in high import tariff industries and low-productivity industries may lobby the government to lower the input tariff, thus firms' product plan may lead to tariff changes and not the opposite. To control for the reverse causality between product scope and tariffs, following Yu (2014), we construct a one-year lag of firm and industry-specific input tariffs .i.e., firm and industry-specific input tariffs are measured by using previous (one-year lag) tariffs with time-invariant weights. Table 4 
presents the 2SLS estimation results, which are consistent with the results above.

Table 4. 2SLS regressions on The Number of (log) HS6-Country Varieties

\begin{tabular}{|c|c|c|c|c|}
\hline & (1) & (2) & (3) & (4) \\
\hline $\begin{array}{l}F I T_{-1} \\
C I T_{-1}\end{array}$ & $\begin{array}{l}-0.045^{*} \\
0.029\end{array}$ & $\begin{array}{l}-0.034 \\
0.043\end{array}$ & $\begin{array}{l}-0.045^{* * *} \\
0.005\end{array}$ & $\begin{array}{l}-0.06^{*} \\
0.045\end{array}$ \\
\hline 2.year & $\begin{array}{l}0.114 * * * \\
0.067\end{array}$ & $\begin{array}{l}0.466^{* * *} \\
0.074\end{array}$ & $\begin{array}{l}0.567 * * \\
0.046\end{array}$ & $\begin{array}{l}0.345^{* *} \\
0.044\end{array}$ \\
\hline 3.year & $\begin{array}{l}0.345^{* * *} \\
0.043\end{array}$ & $\begin{array}{l}0.457 * * * \\
0.057\end{array}$ & $\begin{array}{l}0.334 * * * \\
0.038\end{array}$ & $\begin{array}{l}0.345^{* * *} \\
0.045\end{array}$ \\
\hline 4.year & $\begin{array}{l}0.547 * * * \\
0.067\end{array}$ & $\begin{array}{l}0.864 * * * \\
0.044\end{array}$ & $\begin{array}{l}0.457 * * * \\
0.045\end{array}$ & $\begin{array}{l}0.643 \text { *** } \\
0.043\end{array}$ \\
\hline 5.year & $\begin{array}{l}0.685^{* * * *} \\
0.057\end{array}$ & $\begin{array}{l}0.544 * * * \\
0.045\end{array}$ & $\begin{array}{l}0.456^{* * * *} \\
0.054\end{array}$ & $\begin{array}{l}0.654 * * * \\
0.054\end{array}$ \\
\hline $\begin{array}{l}F I T_{-1} \cdot d i f \\
C I T_{-1} \cdot d i f\end{array}$ & & $\begin{array}{l}-0.084 * * * \\
0.005\end{array}$ & & $\begin{array}{l}0.097^{* * *} \\
0.015\end{array}$ \\
\hline $\begin{array}{l}\mathrm{r} 2 \\
\mathrm{~N}\end{array}$ & $\begin{array}{l}0.864 \\
5425\end{array}$ & $\begin{array}{l}0.934 \\
5425\end{array}$ & $\begin{array}{l}0.896 \\
5425\end{array}$ & $\begin{array}{l}0.967 \\
5425\end{array}$ \\
\hline
\end{tabular}

Note: Table 4 regresses the (log) number of HS6-country varieties on firm- and industry-specific tariffs and cross term with the scope of product differentiation using IV. Regressions include firm fixed effects and year fixed effects. Robust standard errors are clustered by exporter year. Significance levels: ***0.01;**0.05;*0.10.

\section{Conclusions}

Multi-product firms (MPFs) contribute a large percent to production and international trade. Therefore, the success of multi-product exporters in the global marketplace means a lot to a country's exporting growth. Recent literature on multi-product firms shows that product scope is one of the most important sources of exporters' success in international trade. Introducing a new product or a new variety of existing products will increase exporters' revenues in the global marketplace. However, it would prove difficult for firms in developing countries if accessing varieties of key inputs is too costly.

Input trade liberalization provides domestic firms great opportunities to access to cheaper and previously unavailable inputs, not only reducing the import prices of existing inputs but also relaxing technological constraints facing such producers via access to new imported input varieties that were unavailable prior to the liberalization. However, responses are different across firms in industries with different scope of product. While firms in highly differentiated 
industries are more likely to expand their product varieties, firms in non-differentiated industries may not.

Relying on three sets of data: tariff data, product-level trade data and firm-level production data, we construct firm-and industry-specific tariff index, respectively, to reflect the intensive and extensive margin of input trade liberalization using time-invariant input share as weight to avoid the endogenous relationship between tariffs and imports. In addition, since the main interest of our paper is firms' export scope, we make three definitions of firms' export varieties to show that the results are not sensitive to our definition of varieties. In order to investigate heterogeneous impacts of input trade liberalization on firms' export product scope in industries with different scope of product difference, we also classify export products into differentiated and homogeneous goods using Rauch (1999) classification.

As we show, the Chinese data provide robust confirmation of the prediction: comparing changes of export product scope of firms in industries with different scope of product differentiation, we find that while firms in differentiated product scope expand export product scope greatly, firms in non-differentiated product sector do not expand export product scope significantly, which robust to different definitions of varieties.

Since input tariff reductions contribute a lot to Chinese export growth through expanding product scope, more open policies should be implemented to encourage domestic firms to import advanced, critical and important intermediate inputs and equipment.

\section{Acknowledgement and Sponsoring information}

We are grateful to the editor and the anonymous referee for helpful comments. This paper is supported by China National Social Science Foundation (N0.14ZDA082).

\section{References}

Ahn, JaeBin, Amit K. Khandelwal, and Shang-Jin Wei. (2011). The Role of Intermediaries in Facilitating Trade, Journal of International Economics. 84(1). 73-85.

Alexis Antoniades. (2015). Heterogeneous Firms, Quality, \& Trade. Journal of International Economics. 95, 263-273. http://dx.doi.org/10.1016/j.jinteco.2014.10.002

Arkolakis, C., T. Papageorgiou, \& O. Timoshenko. Firm Learning and Growth. [Online] Available: https://sites.google.com/site/olgatimoshenkoecon/research (Setember, 2015).

Baldwin, R., Harrigan, J. (2011). Zeros, Quality, \& Space: Trade Theory and Trade Evidence. American Economic Journal: Microeconomics. $\quad 3(2), \quad 60-88$. http://dx.doi.org/10.1257/mic.3.2.60

Maria Bas \& Vanessa Strauss-Kahn (2015). Input-Trade Liberalization, Export Prices and Quality Upgrading. Journal of International Economics. 95(2015), 250-262. http://dx.doi.org/10.1016/j.jinteco.2014.12.005

Bernard, A. B., S. J. Redding, \& P. K. Schott. (2010). Multiple-Product Firms and Product Switching. American Economic Review, 100(1), 70-97. http://dx.doi.org/10.1257/aer.100.1.70 
Bernard, A. B., S. J. Redding, \& P. K. Schott. (2011). Multi-Product Firms and Trade Liberalization. Quarterly Journal of Economics. 126(3), 1271-1318. http://dx.doi.org/10.1093/qje/qjr021

Chaney, Thomas. (2008). Distorted Gravity: The Intensive and Extensive Margins of International Trade. American Economic Review. 98(4), 1707-1721. http://dx.doi.org/10.1257/aer.98.4.1707

Colin Hottman, Stephen J. Reddingy David E. Weinstein. Quantifying the Sources of Firms Heterogeneity. [Online] Available: http://www.columbia.edu/ dew35/3_Research.html (November 13, 2015).

De Loecker, J., \& F. Warzynski (2012). Markups and Firm-Level Export Status. American Economic Review. 102(6), 2437-2471. http://dx.doi.org/10.1257/aer.102.6.2437

De Loecker, Pinelopi K. Goldberg, Amit K. Khandelwal and Nina Pavcnik (2016). Prices, Markups and Trade Reform. Econometrica. 84(2), 445-510. http://dx.doi.org/10.3982/ECTA11042

Dhingra, S. (2013). Trading Away Wide Brands for Cheap Brands. American Economic Review. 103(6), 2554-2584. http://dx.doi.org/10.1257/aer.103.6.2554

Eckel, C. (2009). Endogenous Sunk Costs, Flexible Manufacturing and the Productivity Effects of International Trade. Scandinavian Journal of Economics. 111(2), 369-386. http://dx.doi.org/10.1111/j.1467-9442.2009.01568.x

Eckel, C., \& J. P. Neary (2010). Multi-Product Firms and Flexible Manufacturing in the Global Economy. Review of Economic Studies. 77(1), 188-217. http://dx.doi.org/10.1111/j.1467-937X.2009.00573.x

Eckel, C., L. Iacovone, B. Javorcik, \& J. P. Neary (2015). Multi-Product Firms at Home and Away: Cost-versus Quality-Based Competence. Journal of International Economics. 95(2), 216-232. http://dx.doi.org/10.1016/j.jinteco.2014.12.012

Flach, Lisandra, Irlacher, Michael. Product versus Process: Innovation Strategies of Multi-Product Firms. [Online] Available at SSRN:http://ssrn.com/abstract=2622451 (June 24, 2015).

Guohua Peng, \& Fan Xia. (2013). Research on Two Margins and Core-Competence Product of China's Multi-Product Firms. The World Economy. 2013(2), 42-63.

Haichao F, Yao Amber Li, Stephen R. Yeaple (2015). Trade Liberalization, Quality, and Export Prices. The Review of Economics and Statistics. 97(5), 1033-1051. doi:10.1162/REST_a_00524

Haichao Fan, Xiang Gao, Yao Amber Li \& Tuan Anh Luong. Trade Liberalization and Markups: Micro Evidence from China. [Online] Available: http://www.tuanluong.com/working-papers.html

Hallak, Juan-Carlos, Sivadasan, Jagadeesh (2013). Product and process productivity: 
Implications for quality choice and conditional exporter premia. Journal of International Economics. 91, 53-67. http://dx.doi.org/10.1016/j.jinteco.2013.05.001

Larry Qiu, \& Miaojie Yu (2014). Multiproduct Firms, Export Product Scope, and Trade Liberalization: The Role of Management Efficiency. HKIMR Working Paper No.02/2014. Available at SSRN: http://ssrn.com/abstract=2386412

Mayer, Thierry, Marc Melitz, \& Gianmarco I. P. Ottaviano (2014). Market Size, Competition, and the Product Mix of Exporters. American Economic Review. 104. 495-536. http://dx.doi.org/10.1257/aer.104.2.495

Mary Amiti \& Amit K. Khandelwal (2013). Import Competition and Quality Upgrading. The Review of Economics and Statistics. 95(2), 476-490. http://dx.doi.org/10.1162/REST_a_00271

Melitz, M. \& G. I. P. Ottaviano (2008). Market Size, Trade and Productivity. Review of Economic Studies. 75(1), 295-316. http://dx.doi.org/10.1111/j.1467-937X.2007.00463.x

Miaojie Yu (2014). Process Trade, Tariff Reductions and Firm Productivity: Evidence from Chinese Firms. The Economic Journal. 125. 943-988. http://dx.doi.org/10.1111/ecoj.12127

Michael Irlacher (2014). Multi-Product Firms, Endogenous Sunk Costs, and Gains from Trade through Intra-Firm Adjustments. Munich Discussion Paper No. 2014-31. [Online] Available: http://epub.ub.uni-muenchen.de/21023/

Richard Upward, Aheng Wang \& Jinghai Zheng (2013). Weighing China's Export Basket:The Domestic Content and Technology Internsity of Chinese Exports. Journal of Comparative Economics. 41(2), 527-543. http://dx.doi.org/10.1016/j.jce.2012.07.004

P. Goldberg et al. (2013). Variety In, Variety Out: Imported Inputs and Product Scope Expansion in India. in Reforms and Economic Transformation in India, edited by J. Bhagwati and A. Panagariya, Oxford University Press.

P. Goldberg et al. (2010). Imported Intermediate Inputs and Domestic Product Growth: Evidence from India. Quarterly Journal of Economics. 125(4), 1727-1767. http://dx.doi.org/10.1162/qjec.2010.125.4.1727

P. Goldberg et al. (2009). Trade Liberalization and New Imported Inputs. American Economic Review Papers and Proceedings. 99(2), 494-500. http://dx.doi.org/10.1257/aer.99.2.494

Qiu, L. D., \& W. Zhou (2013). Multiproduct Firms and Scope Adjustment in Globalization. $\begin{array}{llll}\text { Journal of International } & \text { Economics. } & \text { 91(1), }\end{array}$ http://dx.doi.org/10.1016/j.jinteco.2013.04.006

Rauch, James E. (1999). Networks versus markets in international trade. Journal of International Economics. 48(1), 7-35. http://dx.doi.org/10.1016/S0022-1996(98)00009-9

Tang, Heiwai \& Yifan Zhang (2012). Quality Differentiation and Trade Intermediation. [Online] Available at SSRN: http://ssrn.com/abstract=2368660 (September 20, 2012) 


\section{Macrothink}

Business and Economic Research ISSN 2162-4860 2016, Vol. 6, No. 2

Volker Nocke \& Stephen Yeaple (2014). Globalization and Multiproduct Firms. International Economic Review, 55(4), 993-1018. http://dx.doi.org/10.1111/iere.12080

\section{Copyright Disclaimer}

Copyright for this article is retained by the author(s), with first publication rights granted to the journal.

This is an open-access article distributed under the terms and conditions of the Creative Commons Attribution license (http://creativecommons.org/licenses/by/3.0/). 